\title{
ANALISIS PERBANDINGAN VOLATILITAS INDEKS HARGA SAHAM IHSG DAN JII
}

\author{
Amirul Mukmin $^{1}$ dan Firmansyah ${ }^{2}$ \\ 1 Program Studi Akuntansi Syariah, Sekolah Tinggi Ekonomi Islam SEBI, \\ Depok, Jawa Barat. Email: amirsurin@gmail.com \\ 2Program Studi Perbankan Syariah, Sekolah Tinggi Ekonomi Islam SEBI, \\ Depok, Jawa Barat. Email: firm134@gmal.com
}

\begin{abstract}
ABSTRAK: pasar modal syariah memiliki beberapa perbedaan dengan konvensional pada jenis jenis surat berharga dan tingkat risikonya. Saham adalah salah satu surat berharga yang memiliki risiko tinggi. Salah satu risiko yang ada adalah fluktuasi harga yang di kenal dengan volatilitas. Tujuan dari penelitian ini adalah membandingkan volatilitas risiko indek harga saham di Indonesia dengan metode GARCH. Data yang di gunakan adalah dari IHSG dan JII mulai dari 1 mei 2013 sampai 31 desember 2014. Penelitian ini menemukan bahwa volatilitas mempengaruhi IHSG dan JII. Hasil forecast variance menunjukan bahwa fluktuasi dan proporsi varian IHSG dan JII 0.05. namun demikian, jika dilihat dari proporsi divergennya adalah 0.05 dan 0.04 artinya volatilitas risiko IHSG lebih tinggi daripada JII. Namun jika di lihat dari nilai akurasinya, JJI lebih Akurat daripada IHSG.
\end{abstract}

\section{Kata kunci: IHSG, JII, Volatilitas, Pasar modal syariah dan GARCH.}

\begin{abstract}
Islamic Capital marketand conventional have some type securities which have different risks levels. A stock is one of security among other securities that have the high level of risk. One of the risk that exist in the stock is fluctuations price, it is commonly called as volatility. The aimed of this research is to know the comparative volatility risks of stock price index in Indonesia with GARCH Method. The samples taken in this study is Indek Harga Saham Gabungan (IHSG) and Jakarta Islamic Indexs (JII), from 1 May 2013 to 31 December 2014. The research found that there the volatility influence the IHSG and JII. The forecast of variance results showed that the fluctuations and the proportion of the variant of the IHSG are same as with JII that is 0.05. Nevertheless, when viewed from diverge proportion of IHSG and JII each of them are 0,05 and 0,04, it means the volatility risk IHSG is higher than JII and if it seen from the accuracy percentage of forecast, JII is more accurate that is amounted $16.83 \%$ contrasted with IHSG it is $12.99 \%$.
\end{abstract}

Keywords: ISHG, JII, volatility, Islamic capital maret and GARCH 


\section{PENDAHULUAN}

Pasar modal merupakan pasar untuk berbagai instrumen keuangan jangka panjang yang bisa diperjualbelikan, baik surat utang (obligasi), ekuiti (saham), reksa dana, instrumen derivatif maupun instrumen lainnya. Pasar modal menjadi sarana pendanaan bagi perusahaan maupun institusi lain. Dana yang diperoleh dari pasar modal dapat digunakan untuk pengembangan usaha, ekspansi, penam- bahan modal kerja dan lainlain. Pasar modal juga menjadi sarana bagi masyarakat untuk berinvestasi. (Kartika, 2010).

Kemajuan perekonomian suatu Negara bisa diukur dengan berkembangnya Pasar modal dinegara tersebut. Pasar modal memungkinkan percepatan pertumbuhan ekonomi dengan memberikan kesempatan bagi para perusahaan untuk dapat memanfaatkan dana lansung dari masyarakat tanpa harus menunggu tersedianya dana dari operasi perusahaan. Pasar modal berperan menjalankan dua fungsi secara simultan berupa fungsi ekonomi yang mewujudkan pertemuan dua kepentingan, yaitu pihak yang memiliki kelebihan dana dan pihak yang membutuhkan dana, dan fungsi keuangan dengan memberikan kemungkinan dan kesempatan ini untuk memperoleh imbalan bagi pemilik dana investasi (Soemitra, 2009).

Pasar modal, baik pasar modal konvensional maupun pasar modal syariah memperdagangkan beberapa jenis sekuritas yang mempunyai tingkat risiko yang berbeda. Saham merupakan salah satu sekuritas diantara sekuritas-sekuritas lainnya yang mempunyai tingkat risiko yang tinggi. Risiko tinggi tercermin dari ketidakpastian return yang akan diterima oleh investor di masa datang (Hamzah:2005). Pergerakan saham di Bursa Efek Indonesia saat ini kondisi harga saham sangatlah fluktuatif dan mudah terpengaruh oleh keadaan ekonomi yang ada di dalam Negara ataupun di luar Negara. Hal tersebut bisa kita lihat dari garafik pergerakan saham IHSG, LQ45, dan JII dari 2004 s/d 24 oktober 2014 di bawah ini:

Grafik 1.1. Pergerakan saham IHSG, LQ45, dan JII

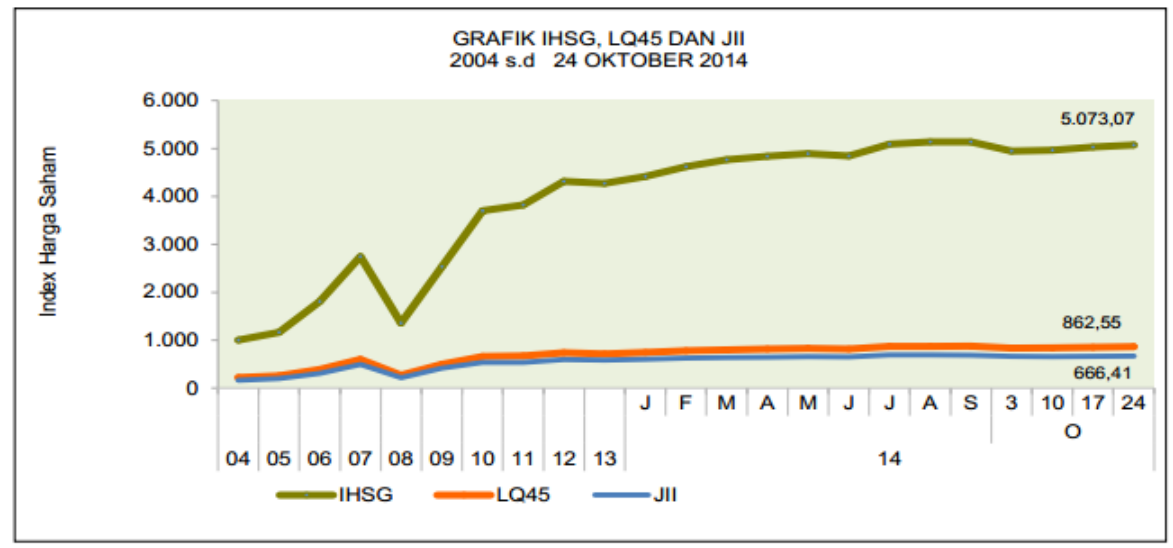

Sumber: www.ojk.go.id

Berdasarkan grafik tersebut bisa kita lihat ketiga saham yang ada di bursa efek Indonesia pada tahun 2007 mengalami kenaikan, sedangkan di tahun 2008 menunjukkan 
Jurnal Ekonomi dan Perbankan Syariah

Vol. 3. No.1, April 2015: 69-84, ISSN (cet): 2355-1755

penurunan dan pada tahun berikutnya saham IHSG, LQ45, dan JII masing-masing mengalami kenaikan kembali.

Terkait pasar modal atau pasar modal syariah, hampir semua investor mengetahui bahwa risiko harus dipertimbangkan dalam menentukan nilai dan membuat pilihan investasi (Aswandi, Anggreyani, \& Nurfalah, 2014), dan setiap investor yang melakukan investasi saham mempunyai dua kemungkinan yaitu mendapatkan capital gain dan deviden atau sebaliknya mengalami capital loss dan tidak mendapat deviden. (Kartika, 2010), pada prinsipnya investor tidak ingin mengambil resiko yang terlalu tinggi, apabila dilihat dari kesediannya menanggung resiko, Menurut Maskur (2009) Investor dikategorikan dalam tiga tipe yaitu, pertama investor yang berani mengambil resiko atau disebut risk taker/risk lover/risk seeker. Kedua, investor yang takut atau enggan resiko, biasa disebut risk averter atau risk aversion. Ketiga, investor yang takut tidak, berani juga tidak disebut risk moderate/moderate investor atau indifference investor. Dan didalamkondisi yang lain ada beberapa kondisi investor di pasar modal Indonesia yang dapat berkontribusi terhadap lemahnya efisiensi pasar, sebagaimana yang dikemukahan oleh Sukamulja (2011) dalam (Tim Studi Kementrian Keuangan Indonesia, 2011) bahwasanya investor memiliki informasi yang tidak simetris, Investor cenderung irasional dalam mengambil keputusan, di antaranya karena pengetahuan yang kurang memadai, Investor seringkali bereaksi berlebihan terhadap suatu perkembangan terbaru, Investor cenderung kurang mengikuti konsep investasi pasar modal (misalnya, mempertimbangkan risiko dan imbal hasil serta berinvestasi untuk jangka panjang).

Menurut kondisi diatas idealnya Fungsi mekanisme pasar akan bisa lebih efektif apabila ada informasi-informasi yang bisa menunjangnya. Ada bebrapa sarana informasi yang bisa disampaikan kepada nasabah, investor, pengawas dan regulator seperti laporan keuangan tahunan, informasi pasar saham, dan lain-lain. Karena dengan informasi yang didapat oleh nasabah maupun investor akan menjadikan sebuah acuan bagi mereka dalam menyalurkan dananya dengan tingkat return dan risikonya. Oleh karena itu perusahaan harus mengungkapkan informasi yang jelas kepada nasabah maupun investor. Menurut (Tariqullah Khan, 2008)Informasi pasar dikatakan efektif apabila a) ada informasi tentang risiko yang dihadapi, dan b) proses dari manajemen risiko tersebut.

Didalam pasar modal ada beberapa informasi yang harus diketahui oleh para investor yang mana salah satunya adalah mengenai informasi pergerakan naik dan turunnya saham atau yang biasa disebut dengan istilah volatility, Apabila investor ingin mendapatkan keuntungan baik berupa capital gain ataupun deviden maka investor harus memahami volatilitas yang terjadi sehingga dia bisa memanfaatkan efek dari volatilitas itu. Oleh karena itu, untuk mengantisipasi hal tersebut pengambil kebijakan ataupun investor dituntut untuk memiliki pemahaman mengenai sumber-sumber dan karakteristik volatilitas di pasar saham, sebagai bekal dalam mengambil langkah-langkah yang diperlukan (Tim Studi Kementrian Keuangan Indonesia, 2011) Namun ironisnya untuk mengetahui hal tersebut para investor masih mengalami kesulitan mendapatkan informasi-informasi yang harusnya bisa didapatkan, sehingga hal ini akan menimbulkan sedikit kegelisahan kepada investor yang akan menanamkan modalnya di Indonesia, kondisi seperti ini sebagaimana yang digambarkan oleh (Tim Studi Kementrian Keuangan 
Indonesia, 2011)bahwa investor di pasar modal Indonesia belum bisa memperoleh informasi yang memadai sehingga hal ini terkadang menimbulkan kesalahan penentuan harga (mispricing).

Volatilitas saham menjadi perhatian pelaku pasar untuk menentukan strategi yang tepat dalam berinvestasi untuk memperoleh return dari selisih harga beli dengan harga jual (Sandrasari, 2010), maka salah satu informasi yang harus diketahui oleh investor sebelum menanamkan modalnya adalah tingkat volatilitas harga saham (Kartika, 2010), Menurut (Firmansyah, 2006)volatilitas merupakan pengukuran statistik untuk fluktuasi harga suatu sekuritas atau komoditas selama periode tertentu. Mengingat volatilitas dapat direpresentasikan dengan simpangan baku (standard deviation), publik juga mempersepsikan volatilitas sebagai risiko. Semakin tinggi tingkat volatilitas, semakin tinggi pula tingkat ketidakpastian dari imbal hasil (return) saham yang dapat diperoleh. Saham-saham yang tergabung dalam indeks harga pasti menghadapi pasar yang dinamis karena para pemain mudah masuk atau keluar pasar. Hal nilah yang menyebabkan terjadinya fluktuasi harga saham atau istilahnya volatilitas (Kartika, 2010). Sebagaimana penelitian yang dilakukan oleh (Tim Studi Kementrian Keuangan Indonesia, 2011) menyatakan bahwa volatilitas di pasar keuangan menggambarkan tingkat risiko yang dihadapi pemodal karena mencerminkan fluktuasi pergerakan harga saham. Dalam berbagai kasus, volatilitas di pasar keuangan dapat mengakibatkan dampak yang signifikan bagi perekonomian.

Data keuangan seperti indeks harga saham, tingkat bunga, nilai tukar, inflasi dan lain sebagainya sering memiliki volatilitas yang tinggi (Juanda \& Junaidi, 2012) lebih lanjut mereka mengungkapkan untuk menangani volatilitas maka diperlukan dengan sebuah model Autoregressive Conditional Heteroscedasticity (ARCH) yang dikembangkan oleh Enggle (1982), didalam Juanda dan Junaidi (2012) bahwasanya Bollerslev (1986) mengungkapkan bahwa ragam residual juga tergantung pada periode yang lalu. Berdasarkan penelitian terdahulu yang dilakukann (Aswandi, Anggreyani, \& Nurfalah, 2014)tentang perbandingan pasar modal indonesia dan pakistan disebutkan dalam (Huda dan Barata, 2014) bahwa Alessandro (2007) dalam penelitiannya menuliskan bahwa model GARCH , baik mean modelmaupun variance model digunakan untuk memprediksi return dan risiko selama beberapa periode kedepan. Berdasarkan pertimbangan dari peramalan return dan risiko dari portofolio tersebut, maka akan dipertimbangkan portofolio mana yang terbaik. Sedangkan penelitian tentang perbandingan kinerja saham konvesional dan saham syariah yang dilakukan oleh (lestari, 2008)dengan pendekatan volatilitas dan menggunakan model GARCH bahwasanya JII cukup superior dibandingkan LQ45 dan JCI. Hal ini dapat diartikan bahwa pasar JII dapat diandalkan dalam berinvestasi karena relative kuat dan tidak terpengaruh oleh shock dari pasar lain.

Maka dari itu, peneliti tertarik untuk menganalisis secara komparatif volatilitas pasar modal dan pasar modal syariah yang ada di Indonesia dengan metode GARCH (Generalized Autoregressive Conditional Heteroscedasticity). Berdasarkan sharia economic outlook 2014 (Tim Penyusun MES, 2014), Kinerja indeks saham syariah seperti Jakarta Islamic Index (JII) selama setahun terakhir tidak bisa lepas dari kondisi indeks harga saham gabungan (IHSG). Oleh karena itu, Pada pasar modal Indonesia akan dianalisis index saham Jakarta Islamic Index(JII) dan Indeks Harga Saham Gabungan (IHSG). 


\section{TELAAH PUSTAKA}

\section{Indek Harga Saham}

Indek harga saham merupakan indicator yang menggambarkan pergerakan hargaharga saham (Gumanti, 2011). Indeks harga saham adalah suatu indikator yang menunjukkan pergerakan harga saham. Indeks berfungsi sebagai indikator trend pasar, artinya pergerakan indeks menggambarkan kondisi pasar pada suatu saat, apakah pasar sedang aktif atau lesu. Pergerakan indeks menjadi indikator penting bagi para investor untuk menentukan apakah mereka akan menjual, menahan atau membeli suatu atau beberapa saham. Karena harga-harga saham bergerak dalam hitungan detik dan menit, maka nilai indeks juga bergerak turun naik dalam hitungan waktu yang cepat pula (Kartika, 2010).

Bursa Efek Indonesia memiliki 5 macam Indeks Harga Saham (Gumanti, 2011) yaitu:

1. Indeks Harga Saham Gabungan (IHSG), menggunakan semua saham tercatat sebagai komponen penghitungan indeks.

2. Indeks Sektoral, menggunakan semua saham yang termasuk dalam masingmasing sector.

3. Indeks LQ45, menggunakan 45 saham yang terpilih setelah melalui bebrapa macam seleksi.

4. Jakarta Islamic Indeks (JII), menggunakan 30 saham yang masuk dalam kriteria syariah dan termasuk saham yang luquid.

5. Indeks Individual, yaitu indeks harga masing-masing saham terhadap harga dasarnya.

\section{Indeks Harga Saham Gabungan (IHSG)}

Indeks harga saham gabungan (disingkat IHSG, dalam Bahasa Inggris disebut juga Jakarta Composite Index, JCI, atau JSX Composite) merupakan salah satu indeks pasar saham yang digunakan oleh Bursa Efek Indonesia (BEI; dahulu Bursa Efek Jakarta (BEJ)). Diperkenalkan pertama kali pada tanggal 1 april 1983, sebagai indikator pergerakan harga saham di BEJ. Indeks ini mencakup pergerakan harga seluruh saham biasa dan saham preferen yang tercatat di BEI . hari dasar untuk perhitungan IHSG adalah tanggal 10 Agustus 1982. Pada tanggal tersebut, indeks ditetapkan dengan nilai dasar 100 dan saham tercatat pada saat itu berjumlah 13 saham (Maskur, 2009).

\section{Jakarta Islamic Indeks (JII)}

Di Bursa Efek Indonesia terdapat Jakarta Islamic Indeks (JII) yang merupakan 30 saham yang memenuhi kreteria syariah yang ditetapkan dewan pengawas syariah (DSN). Indeks JII dipersiapkan oleh PT. Bursa Efek Indonesia (BEI) bersama dengan PT. Dana Reksa Investment Manajemen (DIM) (Rodoni \& Hamid, 2008).

Menurut (Soemitra, 2009)Jakarta Islamic Indeks (JII) dimaksudkan untuk digunakan sebagai tolak ukur (Benchmark) untuk mengukur kinerja suatu investasi pada saham dengan basis syariah. Melalui indeks ini diharapkan dapat meningkatkan kepercayaan investor untuk mengmembangkan investasi dalam ekuiti secara syariah. BEI 
menetapkan saham-saham yang akan masuk dalam perhitungan Jakarta Islamic indeks sesuai dengan kategori sebagai berikut yaitu; (Gumanti, 2011)

a. Memilih kumpulan saham dengan jenis usaha utama yang tidak bertentanga dengan prinsip syariah dan sudah tercatat lebih dari 3 bulan (kecuali termasuk dalam 10 kapitalisasi besar).

b. Memilih saham berdasarkan laporan keuangan tahunan atau tenaga tahun terakhir yang memiliki rasio kewajiban terhadap aktiva maksimal sebesar $90 \%$.

c. Memilih 60 saham dari susunan saham di atas berdasarkan urutan rata-rata kapitalisasi pasar (market capitalization) terbesar selama satu tahun terakhir.

d. Memilih 30 saham dengan urutan berdasarkan tingkat likuiditas rata-rata nilai perdagangan reguler selama satu tahun terakhir.

Gambar 2.1Kriteria Investasi Islami Berdasarkan Fatwa DSN

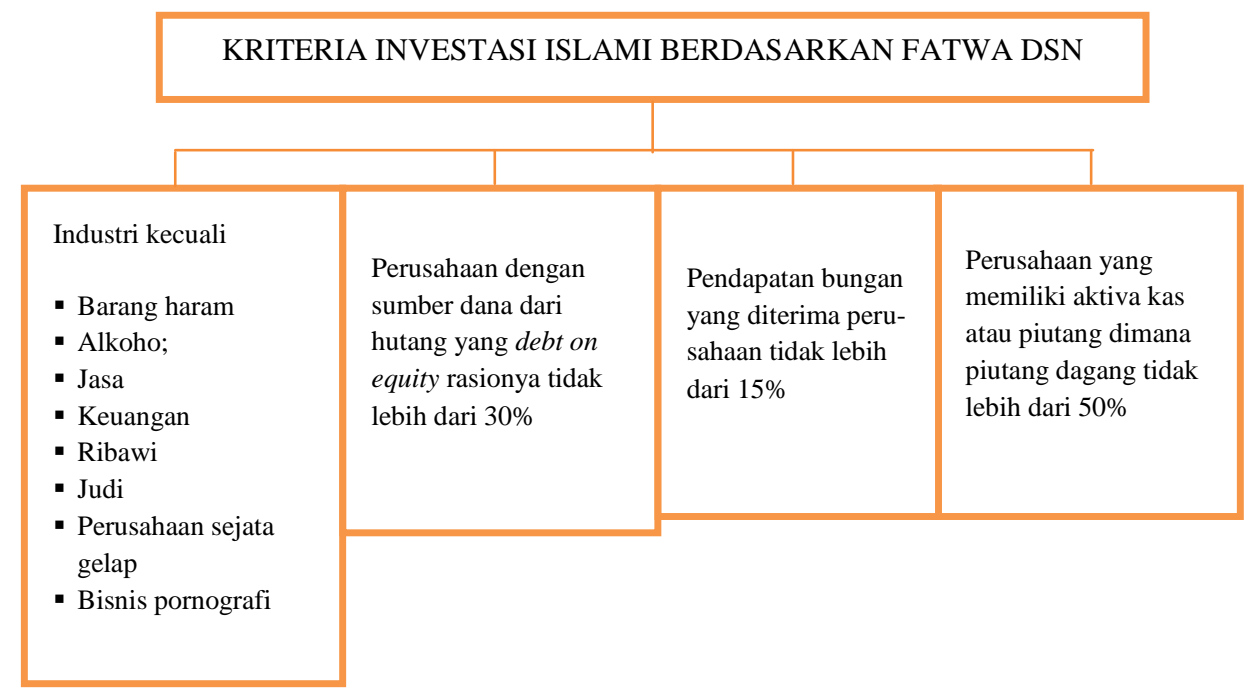

Sumber : (Rodoni \& Hamid, 2008)

\section{Volatilitas}

Volatilitas adalah suatu ukuran ketidakpastian dari suatu deret waktu keuangan atau resiko yang mungkin dihadapi investor dalam perdagangan saham (Rojin, Kusdarwati, \& Sumarningsih). Menurut (Juanda \& Junaidi (2012) Volatility berasal dari kata dasar volatile, yang mengacu pada kondisi yang berkonotasi tidak stabil, cendrung bervariasi, dan sulit diperkirakan. Menurut Firmansyah (2006), volatilitas merupakan pengukuran statistik untuk fluktuasi harga suatu sekuritas atau komoditas selama periode tertentu. Mengingat volatilitas dapat direpresentasikan dengan simpangan baku (standard deviation). Semakin tinggi tingkat volatilitas, semakin tinggi pula tingkat ketidakpastian dari imbal hasil (return) saham yang dapat diperoleh.

Secara umum, volatilitas di pasar keuangan menggambarkan tingkat risiko yang dihadapi pemodal karena mencerminkan fluktuasi pergerakn harga saham (Tim Studi Kementrian Keuangan Indonesia, 2011). 
Jurnal Ekonomi dan Perbankan Syariah

Vol. 3. No.1, April 2015: 69-84, ISSN (cet): 2355-1755

Dengan demikian, dapat dipahami bahwa volatilitas adalah fluktuasi pergerakan saham yang direpresentasikan dengan standard deviation yang berkonotasi tidak stabil dan sulit untuk diperkirakan.

\section{METODE PENELITIAN}

Penelitian ini menggunakan analisis komparatif dengan pendekatan kuantitatif yaitu penelitian yang dilakukan tidak untuk secara lansung menjelaskan hubungan sebab akibat, akan tetapi melakukan perbandingan antara beberapa situasi dan atas dasar itu dilakukan sebuah dugaan mengenai apa penyebab situasi yang terjadi (Ferdinand:2005). Sedangkan pendekatan kuantitatif menurut Sugiyono (2011), merupakan penitikberatan terhadap pembuktian hipotesis. Pendekatan kuantitatif berupaya mengukur suatu konsep atau variabel sehingga mudah dipahami.

jenis data yang digunakan dalam penelitian ini adalah data kuantitatif. Data kuantitatif merupakan data berupa angka-angka yang diperoleh peneliti dari berbagai sumber, baik data primer maupun data sekunder. Penelitian ini menggunakan data sekunder, yaitu data yang diambil dari sumber-sumber yang dapat dipercaya dan dapat dipertanggung jawabkan secara il,iah, yaitu dengan mentabulasi data time series harga saham yang ada di website $i d x, o j k$, dan yahoo finance.

Populasi yang diambil dalam penelitian ini adalah seluruh indeks haraga saham yang ada di bursa efek Indonesia. Sedangkan sampel data yang diambil dalam penelitian ini hanya Indek Harga Saham Gabungan (IHSG) dan Jakarta Islamic Indeks (JII) berdasarkan data time series per hari dari tanggal 01 Juli 2013 sampai dengan 30 November 2014. Sumber yang menjadi rujukan adalah Yahoo Finance.

\section{Teknik Analisis Data}

Mengacu pada penelitian yang dilakukan oleh (Kartika, 2010)Tehnik Analisis Data. Data time series, terutama data finansial seperti data indeks harga saham seringkali bervolatilitas. Implikasi data yang bervolatilitas adalah variance dari error term tidak konstan atau mengalami heteroskedastisitas. Implikasi dari heteroskedastisitas terhadap estimasi OLS tetap tidak bias tetapi standard error dan interval keyakinan menjadi terlalu sempit sehingga dapat memberikan sense of precision yang salah.

Untuk memahami volatilitas digunakan model ARCH/GARCH (Auto Regressive conditional Heteroscedasticity/General Auto Regressive Conditional Heteroscedasticity). Model ini menganggap variance yang tidak konstan (heteroscedasticity) bukan sebagai suatu masalah, tetapi justru dapat digunakan untuk modeling dan peramalan (forecasting). Melalui model ARCH, Engle membandingkan hasil estimasi antara model standar yakni model penaksiran OLS dengan model ARCH melalui penaksiran maksimum likelihood. Hasilnya memperlihatkan bahwa model ARCH mampu memperbaiki hasil dari model OLS dan memperoleh prediksi varian yang lebih relistis (Engle, 1982)

\section{ARMA/ARIMA}

Berikut persamaannya ARMA(1,1):

$$
Y_{t}=\beta_{0}+\beta_{1}+Y_{t-1}+\varepsilon_{t}+\delta_{1} \varepsilon_{t-1}
$$

Di mana $\beta_{0}, \beta_{1}$ dan $\delta_{1}$ adalah parameter, $\varepsilon_{\mathrm{t}}$ adalah random error.

Selanjutnya persamaanARIMA $(1,1,1)$ :

$$
\Delta Y_{t}=\beta_{0}+\beta_{1}+\Delta Y_{t-1}+\varepsilon_{t}+\delta_{1} \varepsilon_{t-1}
$$

Hamilton (1994) deviasidari ARMA $(1,1)$ sebagai berikut: 


$$
\begin{aligned}
& Y_{t}-\varnothing=\beta_{1}\left(Y_{t-1}-\varnothing\right)+\varepsilon_{t}+\delta_{1} \varepsilon_{t-1} \\
& d_{t}=\beta_{1} d_{t-1}+\varepsilon_{t}+\delta_{1} \varepsilon_{t-1} \\
& E\left(d_{t}\right)=E\left(Y_{t}-\varphi\right)=0 \\
& \operatorname{Var}\left(d_{t}\right)=E\left(d^{2} t\right)
\end{aligned}
$$

Kemudian diasumsikan bahwa $d_{t-1}$ dan $\varepsilon_{t}$ tidak berkorelasi.

$$
E\left(d t \varepsilon_{t}\right)=\beta_{1} E\left(d_{t-1}-\varepsilon_{t-1}\right)+\varepsilon_{t}+\delta_{1} \varepsilon_{t-1}=\sigma^{2}(7)
$$

Varian dari $d_{t}$ sebagai berikut:

$$
\begin{aligned}
& \left.\operatorname{Var}\left(d_{t}\right)=\underline{\left(1+\delta^{2}\right.} \underline{1}+2 \underline{\beta}_{1} \underline{\delta}_{1}\right) \sigma^{2}=\gamma_{0} \\
& 1-\beta^{2}{ }_{1}
\end{aligned}
$$

\section{ARCH/GARCH}

Metode umum yang sering digunakan untuk meregresikan sebuah persamaan adalah Ordinary Least Square (OLS) yang mana errornya harus bebas dari autokorelasi dan konstan. Jika error tidak konstan, maka terdapat masalah heteroskedastis, persamaan yang mengandung heteroskedastis tidak dapat menggunakan metode OLS. Namun masalah heteroskedastis ini dapat diselesaikan dengan metode Autoregressive Conditional Heteroskedasticity/Generalized Autoregressive Conditional Heteroskedasticity (ARCH/GARCH).

Kemudian volatilitas harga yang berfluktuasi dengan cepat, memungkinkan variannya tidak konstan. Apabila terjadi hal seperti ini, di mana varian data tidak konstan, maka ARCH/GARCH model menjadi solusi agar data tersebut dapat dianalisis. Berikut ini persamaansederhana dari GARCH (1,1) (Engle, 1987)dalam aswandi (2014).

$$
\begin{aligned}
& Y_{t}=X_{t} \theta+e_{t} \\
& \sigma^{2}{ }_{t}=c+\alpha e^{2}{ }_{t-1}+\beta^{2}{ }_{t-1}
\end{aligned}
$$

dimana: $\mathrm{c}=$ konstan; $e^{2}{ }_{t-1}=\mathrm{ARCH} ; \beta^{2} t-1=\mathrm{GARCH}$.

Persamaan (9) merupakan fungsi variabel eksogenous dengan error. Persamaan (10) adalah varian yang kondisional ( prediksi varian satu periode kedepan tergantung berdasarkan informasi varian pada periode sebelumnya).

\section{HASIL DAN ANALISIS}

\section{Deskripsi data}

Data dan pola pergerakan Indeks Harga Saham Gabungan (IHSG) dan Jakarta Islamic Indeks (JII) terhadap waktu secara berturut-turut dapat dilihat dari gambar berikut ini :

Grafik 4.1 Pergerakan close price IHSG 01 mei 2013-31 desember 2014

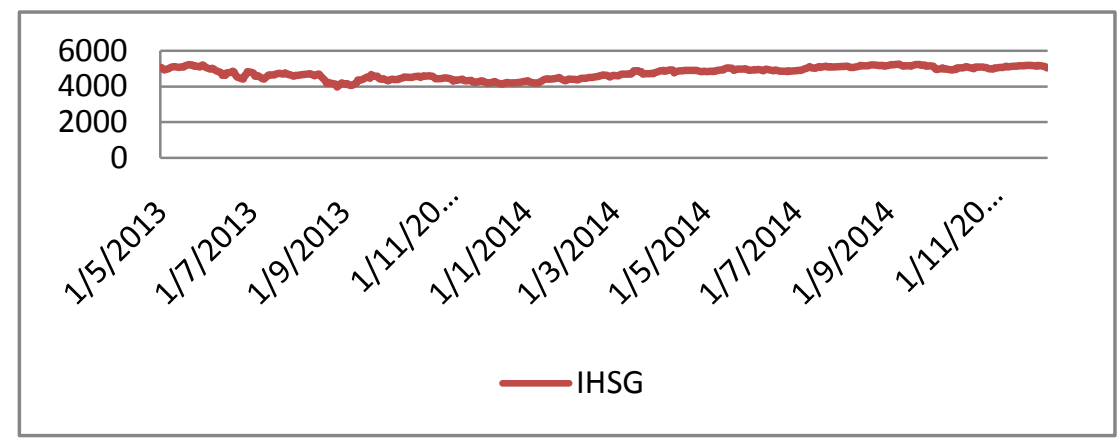

Sumber: yahoo finance 
Grafik 4.2 Pergerakan close price JII 01 mei 2013-31 desember 2014

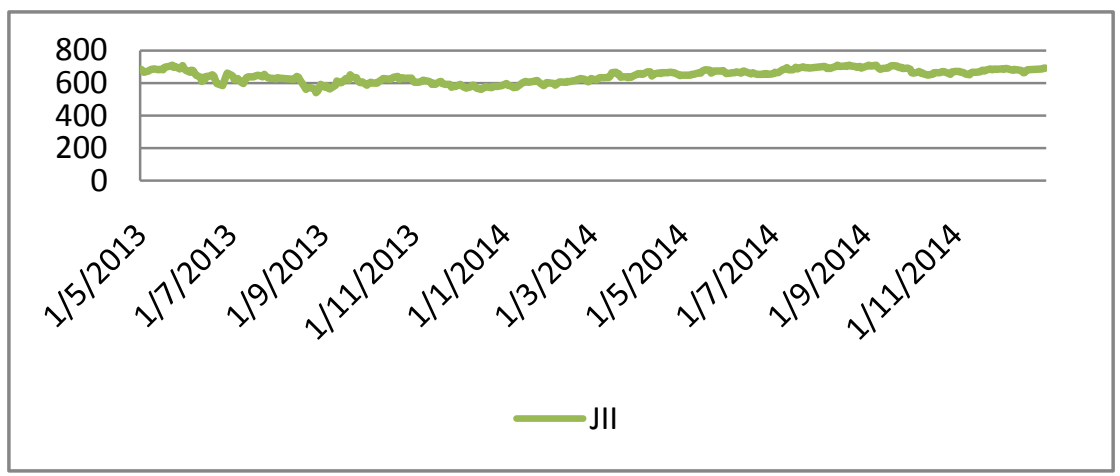

Sumber: yahoo finance

Berdasarkan gambar tersebut, analisis deskriptif secara umum pola pergerakan saham IHSG dan JII hampir sama yaitu pada tahun 2013 mengalami tren penurunan, sedangkan pada tahun berikutnya yaitu 2014 mengalami tren relatif menunjukkan kenaikan. Apabila dilihat dari gambar garik tersebut pergerakan indeks harga saham IHSG dan JII sangat fluktuatif.

\section{Hasil uji stasioner data}

Data harga saham IHSG dan JII menunjukkan data yang tidak stasioner di tingkat level. Untuk mengubah data time series non-stasioner menjadi stasioner dapat dilakukan dengan cara melakukan differencing (Aritonang, 202)Maka harus dirubah terlebih dahulu menjadi data first difference, dengan menggunakan uji Augmented Dickey Fuller (ADF) hasilnya sebagai berikut:

Tabel 3.1 Test Unit root

\begin{tabular}{lccccc}
\hline \multirow{2}{*}{ Variable } & ADF & \multicolumn{3}{c}{ Mackinnon Critical Value } & \\
\cline { 3 - 5 } & Statistic & $1 \%$ & $5 \%$ & $10 \%$ & \\
\cline { 3 - 6 } & & -3.446402 & -2.868511 & -2.570549 & Stationary \\
IHSG & -32.11205 & -3.446777 & -2.868676 & -2.570637 & Stationary \\
\hline JII & -14.84251 & & & & \\
\hline
\end{tabular}

Setelah data dirubah menjadi first difference, data harga saham IHSG dan JII menjadi stasioner. Hal ini dapat dilihat dari probabilitas D(IHSG) 0.0000 yang signifikan terhadap taraf nyata $5 \%$. Selanjutnya D(JII) pun stasioner pada first difference di mana probabilitasnya 0.0000 yang signifikan terhadap taraf nyata $5 \%$. Artinya data D(IHSG) dan D(JII) dapat dianalisis menggunakan ARIMA

\section{Hasil analisis ARIMA}

Penentuan orde ARIMA yang cocok untuk selanjutnya dilakukan analisis adalah dengan cara mengidentifikasi pola Autocorrelation Function (ACF) dan Partial 
78 | Mukmin \& Firmansyah: Analisis Perbandingan Volatilitas Harga Saham ISHG dan JII

Autocorrelation Function (PACF). Tabel corellogram ACF dan PACF dapat dilihat sebagai berikut:

Tabel 4.1. Correlogram ACF dan PACF IHSG dan JII

\begin{tabular}{|c|c|c|c|c|c|c|}
\hline Autocorrelation & Partial Correlation & & $A C$ & PAC & Q-Stat & Prob \\
\hline$\sigma_{1}$ & $\mathrm{G}_{1}$ & & -0.427 & -0.427 & 73.899 & 0.000 \\
\hline 11 & 日, & & -0.016 & -0.242 & 74.007 & 0.000 \\
\hline 1$] 1$ & 日1 & & -0.006 & -0.154 & 74.024 & 0.000 \\
\hline 11 & 1 & 4 & 0.001 & -0.098 & 74.024 & 0.000 \\
\hline iाi & ic & & -0.010 & -0.077 & 74.068 & 0.000 \\
\hline 11 & (c) & 6 & -0.018 & -0.082 & 74.203 & 0.000 \\
\hline 111 & 1 & 7 & 0.010 & -0.057 & 74.247 & 0.000 \\
\hline $1 / 1$ & 1] & 8 & 0.010 & -0.029 & 74.286 & 0.000 \\
\hline i i & iाi & 9 & -0.003 & -0.019 & 74.289 & 0.000 \\
\hline 111 & 11 & 10 & 0.005 & -0.005 & 74.301 & 0.000 \\
\hline 11 & iा & 11 & -0.013 & -0.018 & 74.370 & 0.000 \\
\hline ifi & $i$ & 12 & 0.009 & -0.007 & 74.403 & 0.000 \\
\hline 1. & $i$ & 13 & 0.002 & 0.001 & 74.405 & 0.000 \\
\hline 11 & 11 & 14 & 0.001 & 0.005 & 74.406 & 0.000 \\
\hline 111 & 111 & 15 & -0.016 & -0.015 & 74.507 & 0.000 \\
\hline$i$ & ifi & 16 & 0.001 & -0.018 & 74.507 & 0.000 \\
\hline 111 & 1) 1 & 17 & -0.001 & -0.019 & 74.508 & 0.000 \\
\hline 11 & 111 & 18 & -0.006 & -0.024 & 74.521 & 0.000 \\
\hline 1 & il & 19 & 0.001 & -0.022 & 74.522 & 0.000 \\
\hline$i i$ & ili & 20 & 0.003 & -0.016 & 74.525 & 0.000 \\
\hline $1 / 1$ & 111 & 21 & -0.007 & -0.024 & 74.547 & 0.000 \\
\hline 1.1 & 111 & 22 & -0.000 & -0.024 & 74.547 & 0.000 \\
\hline 111 & id & 23 & -0.010 & -0.034 & 74.589 & 0.000 \\
\hline 11 & in & 24 & -0.004 & $\begin{array}{l}-0.039 \\
\end{array}$ & 74.595 & 0.000 \\
\hline 111 & $1]$ & 25 & 0.021 & -0.008 & 74.780 & 0.000 \\
\hline $1 / 1$ & if & 26 & 0.018 & 0.027 & 74.919 & 0.000 \\
\hline 17 & ifi & 27 & -0.006 & 0.028 & 74.933 & 0.000 \\
\hline 11 & 191 & 28 & -0.007 & 0.016 & 74.952 & 0.000 \\
\hline $1 / 1$ & 11 & 29 & -0.002 & 0.008 & 74.954 & 0.000 \\
\hline 111 & 11 & 30 & 0.009 & 0.018 & 74.987 & 0.000 \\
\hline if, & if & 31 & 0.013 & 0.039 & 75.063 & 0.000 \\
\hline 10 & I 1 & 32 & -0.031 & -0.000 & 75.476 & 0.000 \\
\hline 1) 1 & 1 & 33 & -0.013 & -0.033 & 75.551 & 0.000 \\
\hline 1 & id & 34 & 0.001 & -0.042 & 75.551 & 0.000 \\
\hline iा & 11 & 35 & 0.017 & -0.017 & 75.686 & 0.000 \\
\hline $1 / 1$ & 11 & 36 & -0.008 & -0.018 & 75.718 & 0.000 \\
\hline
\end{tabular}

\begin{tabular}{|c|c|c|c|c|c|c|}
\hline Autocorrelation & Partial Correlation & & $A C$ & PAC & Q-Stat & Prob \\
\hline ו ו ו & ון ו ו & 1 & 0.049 & 0.049 & 0.9745 & 0.324 \\
\hline , & 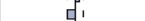 & 2 & -0.106 & -0.109 & 5.4744 & 0.065 \\
\hline , & , & 3 & -0.216 & -0.208 & 24.147 & 0.000 \\
\hline . & 10, & 4 & -0.067 & -0.064 & 25.958 & 0.000 \\
\hline i & 10 & 5 & 0.072 & 0.035 & 28.059 & 0.000 \\
\hline 1 & ili, & $\begin{array}{l}5 \\
6\end{array}$ & 0.048 & $\begin{array}{r}-0.013 \\
-0.03\end{array}$ & 28.974 & 0.000 \\
\hline ifi & i i & 7 & 0.019 & 0.001 & 29.114 & 0.000 \\
\hline 10 & in & 8 & -0.059 & -0.041 & 30.526 & 0.000 \\
\hline 16 & קי & 9 & $\begin{array}{r}-0.059 \\
0.106\end{array}$ & $\begin{array}{r}-0.041 \\
0.132\end{array}$ & 35.113 & 0.000 \\
\hline$\sqrt{1}$ & , & 10 & -0.099 & -0.120 & 39.100 & 0.000 \\
\hline , & , & 11 & -0.057 & -0.051 & 40.421 & 0.000 \\
\hline , & 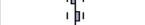 & 12 & $\begin{array}{r}-0.014 \\
\end{array}$ & 0.042 & 40.501 & 0.000 \\
\hline in & c & 13 & $\begin{array}{r}0.014 \\
-0.042\end{array}$ & $\begin{array}{r}0.042 \\
-0.084\end{array}$ & $\begin{array}{l}40.5015 \\
41.215\end{array}$ & 0.000 \\
\hline 16 & 1 & 14 & 0.043 & 0.005 & 41.969 & 0.000 \\
\hline ii & in & 15 & -0.021 & -0.026 & 42.146 & 0.000 \\
\hline 1. & in & 16 & $\begin{array}{l}-0.021 \\
-0.030\end{array}$ & $\begin{array}{l}-0.026 \\
-0.043\end{array}$ & $\begin{array}{l}42.146 \\
42.516\end{array}$ & 0.000 \\
\hline , & ו ומ & 17 & 0.014 & 0.032 & 42.592 & 0.001 \\
\hline ifi & 1 & 18 & 0.035 & -0.003 & 43.097 & 0.001 \\
\hline ici & (1) & 19 & -0.075 & -0.076 & 45.443 & 0.001 \\
\hline , & in & 20 & $\begin{array}{l}-0.075 \\
-0.051\end{array}$ & $\begin{array}{l}-0.030 \\
-0.032\end{array}$ & $\begin{array}{l}45.443 \\
46.522\end{array}$ & 0.001 \\
\hline 10 & 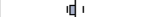 & 21 & -0.043 & -0.074 & 47.301 & 0.001 \\
\hline 11 & iा & 22 & -0.019 & $\begin{array}{l}-0.036 \\
\end{array}$ & 47.455 & 0.001 \\
\hline if & 1. & 23 & $\begin{array}{r}-0.054 \\
0.05\end{array}$ & $\begin{array}{l}-0.000 \\
-0.004\end{array}$ & 48.681 & 0.001 \\
\hline i & i & 24 & 0.083 & 0.058 & 51.584 & 0.001 \\
\hline 1 & 1 & 25 & -0.004 & -0.002 & 51.590 & 0.001 \\
\hline ib & Bi & 26 & 0.087 & 0.110 & 54.783 & 0.001 \\
\hline ומן & 1. & 27 & 0.026 & 0.055 & 55.066 & 0.001 \\
\hline 10 & 111 & 28 & -0.047 & -0.008 & 56.028 & 0.001 \\
\hline (1) & , & 29 & -0.082 & -0.064 & 58.882 & 0.001 \\
\hline , & 111 & 30 & $\begin{array}{l}-0.082 \\
-0.024\end{array}$ & $\begin{array}{l}-0.004 \\
-0.009\end{array}$ & 59.130 & 0.001 \\
\hline iो & 111 & 31 & 0.021 & -0.017 & 59.317 & 0.002 \\
\hline יון ו & iा & 32 & 0.054 & -0.012 & 60.577 & 0.002 \\
\hline 111 & 11 & 33 & 0.021 & -0.008 & 60.762 & 0.002 \\
\hline 101 & ili & 34 & -0.049 & -0.012 & 61.827 & 0.002 \\
\hline 11 & $1 / 1$ & 35 & 0.006 & 0.009 & 61.843 & 0.003 \\
\hline ] & , & 36 & -0.061 & -0.061 & 63.477 & 0.003 \\
\hline
\end{tabular}

Melihat correlogram di atas menunjukkan antara harga saham IHSG dan JII menunjukkan pola yang berbeda . Maka, ada beberapa orde ARIMA yang dapat diujikan untuk IHSG yaitu $\operatorname{ARIMA}(0,1,1), \operatorname{ARIMA}(0,1,2), \operatorname{ARIMA}(1,1,0), \operatorname{ARIMA}(1,1,1)$, ARIMA(1,1,2),ARIMA IHSG $(0,1,3)$, ARIMA IHSG $(1,1,3)$. Sedangkan orde ARIMA yang dapat diujikan untuk JII yaitui ARIMA(0,1,1), ARIMA(1,1,0), ARIMA(1,1,1).

Tabel 4.3. Model ARIMA untuk IHSG

\begin{tabular}{cccccc}
\hline No & $\begin{array}{c}\text { Model } \\
\text { ARIMA }\end{array}$ & PROBABILITAS & SSR & SC & \multicolumn{1}{l}{ AIC } \\
\hline 1 & $0,1,1$ & $\mathrm{MA}(1)=0.0000$ & 0.390770 & -4.070923 & -4.090769 \\
\hline 2 & $0,1,2$ & $\mathrm{MA}(2)=0.2811$ & 0.557256 & -3.716018 & -3.735864 \\
\hline 3 & $1,1,0$ & $\mathrm{AR}(1)=0.0000$ & 0.376695 & -4.105061 & -4.124944 \\
\hline 4 & $1,1,1$ & $\mathrm{AR}(1)=0.0000$ & 0.376687 & -4.090166 & -4.119990 \\
\hline & & $\mathrm{MA}(1)=0.9107$ & & & \\
\hline 5 & $1,1,2$ & $\mathrm{AR}(1)=0.0000$ & 0.376391 & -4.090953 & -4.120778 \\
\hline 6 & $0,1,3$ & $\mathrm{MA}(2)=0.5396$ & & & \\
\hline 7 & $1,1,3$ & $\mathrm{AR}(3)=0.5108$ & 0.558342 & -3.714072 & -3.733918 \\
\hline & & $\mathrm{MA}(3)=0.0000$ & 0.375616 & -4.093012 & -4.122836 \\
\hline
\end{tabular}

Keterangan: SSR = Sum Square Residual; SC = Schwarz Criterion; AIC = Akaike information Criterion; taraf nyata $5 \%$. 
Tabel 4.4. Model ARIMA untuk JII

\begin{tabular}{llllll}
\hline No & $\begin{array}{l}\text { Model } \\
\text { ARIMA }\end{array}$ & PROBABILITAS & SSR & SC & AIC \\
\hline $\mathbf{1}$ & $0,1,1$ & MA(1) $=0.2317$ & 0.090860 & -5.511767 & -5.531876 \\
$\mathbf{2}$ & $1,1,0$ & AR (1) $=0.0329$ & 0.090776 & -5.510092 & -5.530238 \\
$\mathbf{3}$ & $1,1,1$ & AR(1) $=0.8356$ & 0.090701 & -5.495784 & -5.526003 \\
& & MA(1) $=0.7703$ & & & \\
\hline
\end{tabular}

Keterangan: SSR = Sum Square Residual; SC = Schwarz Criterion; AIC = Akaike information Criterion; taraf nyata $5 \%$.

Pada tabel di atas untuk mencari model ARIMA IHSG yang paling baik adalah dengan cara melihat SSR, SC dan AIC yang nilainya terendah di antara tujuh model ARIMA yang diolah Dari tabel tersebut menunjukkan bahwamodel ARIMA yang paling tepat digunakan untuk harga saham IHSG sebagai bahan analisis yaitu model $\operatorname{ARIMA}(0,1,1)$, karena dari nilai SSR, SC dan AIC model ARIMA $(0,1,1)$ tersebut menunjukkan nilai yang paling rendah. Sedangkan model ARIMA yang paling tepat digunakan untuk harga saham JII sebagai bahan analisis yaitu model ARIMA(1,1,0), karena dari nilai SSR, SC dan AIC model ARIMA(1,1,0) tersebut menunjukkan nilai yang paling rendah.

\section{Grafik 4.3. Residual IHSG ARIMA(0,1,1)}

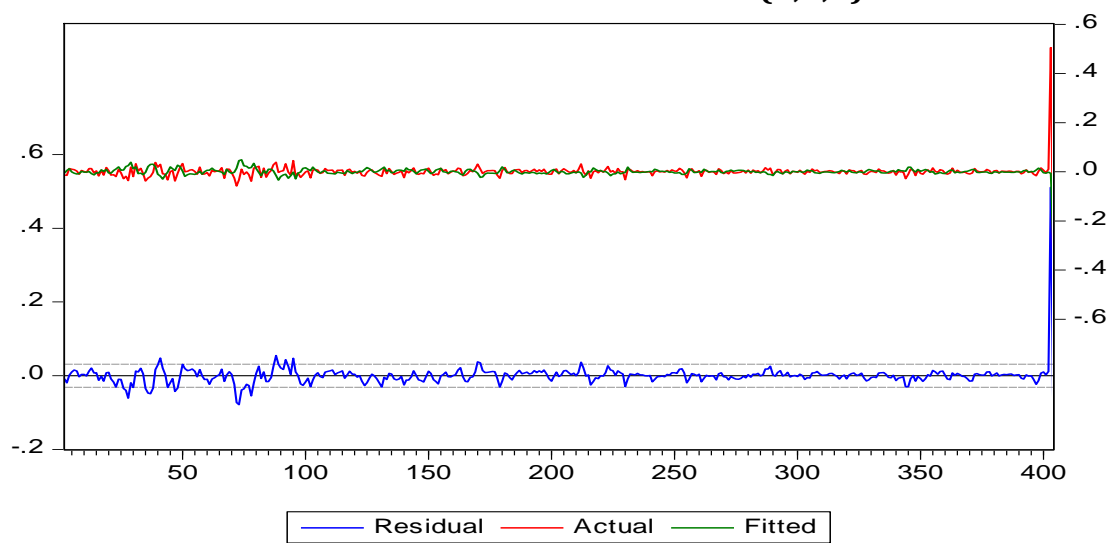

Grafik 4.4 Residual JII ARIMA(1,1,0)

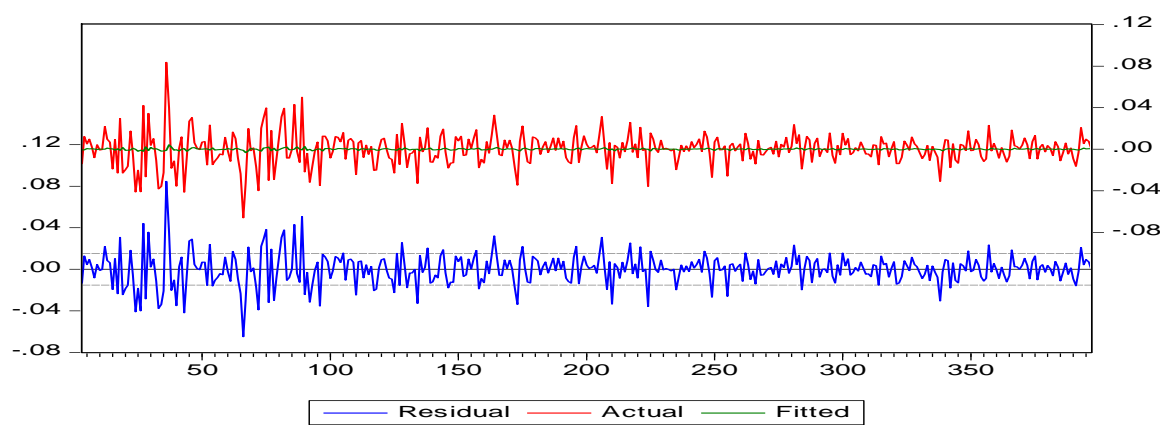

\section{Peramalan (forecasting)}


80 | Mukmin \& Firmansyah: Analisis Perbandingan Volatilitas Harga Saham ISHG dan JII

Setelah menentukan model yang terbaik, langkah selanjutnya adalah peramalan, dalam hal ini menggunakan model ARIMA $(0,1,1)$ untuk IHSG dan ARIMA $(1,1,0)$ untuk JII. Model ini dipilih sesuai dengan kriteria pemilihan model terbaik. Berikut adalah hasil peramalan yang diperoleh dari program e-views.

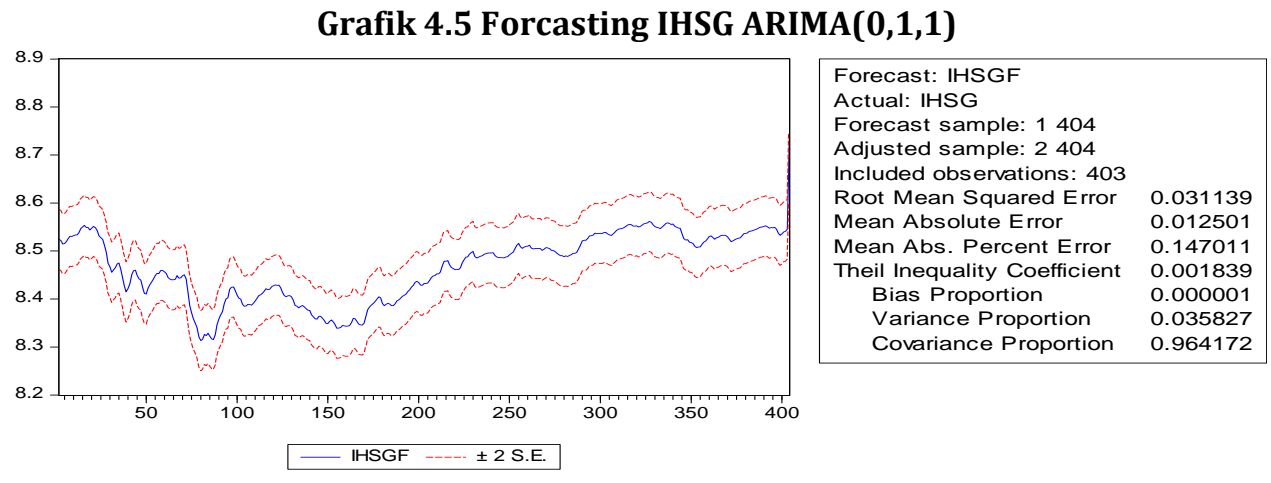

Grafik 4.6 Forecasting JII ARIMA(1,1,0)

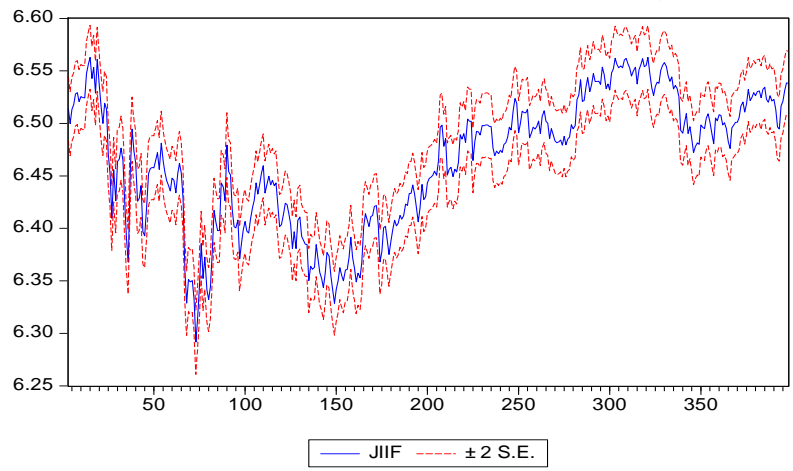

\begin{tabular}{|c|c|}
\hline Forecast: JIIF & \\
\hline Actual: JII & \\
\hline Forecast sample: 1404 & \\
\hline Adjusted sample: 3398 & \\
\hline Included observations: 395 & \\
\hline Root Mean Squared Error & 0.015160 \\
\hline Mean Absolute Error & 0.010860 \\
\hline Mean Abs. Percent Error & 0.168428 \\
\hline Theil Inequality Coefficient & 0.001172 \\
\hline Bias Proportion & 0.000000 \\
\hline Variance Proportion & 0.000006 \\
\hline Covariance Proportion & 0.999994 \\
\hline
\end{tabular}

Berdasarkan grafik Forcasting IHSG ARIMA(0,1,1) dan Forecasting JII ARIMA $(1,1,0)$ hasil peramalan dengan menggunakan program e-views diatas, terbukti bahwa variance proportion IHSG adalah sebesar 0.035827 dan variance proportion JII adalah sebesar 0.000006. hal ini menunjukkan bahwa volatilty Indeks Harga Saham Gabungan (IHSG) lebih tinggi dibandingkan dengan Jakarta Islamic Indexs (JII).

\section{Model ARCH/GARCH \\ Uji Heteroskedasitas}

Tabel 4.5. Heteroskedasticity Test (IHSG)

\begin{tabular}{clll}
\hline \hline F-statistic & 5.490438 & Prob. F(1,400) & 0.0196 \\
Obs*R-squared & 5.443176 & Prob. Chi-Square(1) & 0.0196 \\
\hline \hline
\end{tabular}

Probabilitas uji heteroskedastis menunjukkan probabilitas untuk IHSG sebesar 0.0196 yang signifikan terhadap taraf nyata 5\%. Artinya hasil ini menolak H0 dan menerima H1, di mana H0 tidak terdapat efek ARCH pada model ARIMA. Hasil ini pula 
Jurnal Ekonomi dan Perbankan Syariah

Vol. 3. No.1, April 2015: 69-84, ISSN (cet): 2355-1755

mengindikasikan bahwa metode ARCH/GARCH lebih tepat dan lebih baik dibandingkan dengan metode ARMA/ARIMA.

Tabel4.6 . Heteroskedasticity Test (JII)

\begin{tabular}{llll}
\hline \hline F-statistic & 18.32532 & Prob. F(1,392) & 0.0000 \\
Obs*R-squared & 17.59622 & Prob. Chi-Square(1) & 0.0000 \\
\hline \hline
\end{tabular}

Probabilitas uji heteroskedastis menunjukkan probabilitas untuk IHSG sebesar 0.0000 yang signifikan terhadap taraf nyata 5\%. Artinya hasil ini menolak H0 dan menerima H1, di mana H0 tidak terdapat efek ARCH pada model ARIMA. Hasil ini pula mengindikasikan bahwa metode ARCH/GARCH lebih tepat dan lebih baik dibandingkan dengan metode ARMA/ARIMA.

\section{Hasil analisis ARCH/GARCH}

Model orde ARCH/GARCH yang digunakan dalam penelitian ini sesuai dengan model orde ARIMA. Dari hasil analisis model orde ARIMA dilakukan pengujian apakah benar terdapat efek ARCH dalam model orde ARIMA tersebut, maka dilakukan uji heteroskedastis yang hasilnya signifikan tolak H0.

Tabel 4.7. Testing ARCH/GARCH IHSG ARIMA(0,1,1)

\begin{tabular}{|c|c|c|c|c|c|}
\hline Koefesien & ARCH (1) & ARCH (2) & $\begin{array}{c}\text { ARCH } \\
\text { (3) }\end{array}$ & $\begin{array}{c}\text { GARCH } \\
(1,1)\end{array}$ & $\begin{array}{c}\text { GARCH } \\
(1,3)\end{array}$ \\
\hline $\mathrm{C}$ & 1254.357 & 0.000859 & 0.000844 & 1275.203 & $-1.15 \mathrm{E}-05$ \\
\hline $\mathrm{e} 1$ & 0.0000 & 0.0000 & 0.0000 & 0.0000 & 0.0000 \\
\hline e2 & & 0.0003 & 0.0062 & & \\
\hline$\alpha 1$ & & & & 0.8043 & 0.9255 \\
\hline$\alpha 2$ & & & & & 0.4342 \\
\hline AIC & 12.52390 & -4.34859 & $\begin{array}{l}-334998 \\
4.3\end{array}$ & 12.52874 & -5.068634 \\
\hline SC & 12.54375 & -4.31882 & $\begin{array}{l}-295306 \\
\end{array}$ & 12.55850 & -5.019019 \\
\hline Koefesien & $\begin{array}{l}\text { GARCH } \\
(2,1)\end{array}$ & $\begin{array}{l}\text { GARCH } \\
(2,2)\end{array}$ & $\begin{array}{l}\text { GARCH } \\
(2,3)\end{array}$ & $\operatorname{GARCH}(3,2)$ & $\begin{array}{l}\text { GARCH(3,3 } \\
\text { ) }\end{array}$ \\
\hline $\mathrm{C}$ & 0.001006 & -2.92 & 0.000209 & 0.000216 & 0.000515 \\
\hline $\mathrm{e} 1$ & 0.0000 & 0.0000 & 0.0804 & 0.0145 & 0.4530 \\
\hline $\mathrm{e} 2$ & 0.0000 & 0.0000 & 0.0640 & 0.0603 & 0.1309 \\
\hline$\alpha 1$ & 0.0000 & 0.0000 & 0.0003 & 0.4110 & 0.6731 \\
\hline$\alpha 2$ & & 0.0000 & 0.8022 & 0.2763 & 0.8384 \\
\hline AIC & -4.228520 & $\begin{array}{l}- \\
5.121212\end{array}$ & $\begin{array}{l}- \\
4.290010 \\
\end{array}$ & -4.289809 & -4.273725 \\
\hline SC & -4.188828 & $\begin{array}{l}- \\
5.071598\end{array}$ & $\begin{array}{l} \\
4.230473\end{array}$ & -4.230271 & -4.204264 \\
\hline
\end{tabular}

Tabel4.8 . Testing ARCH/GARCH JII ARIMA(1,1,0) 
82 | Mukmin \& Firmansyah: Analisis Perbandingan Volatilitas Harga Saham ISHG dan JII

\begin{tabular}{|l|c|c|c|}
\hline Koefesien & ARCH (1) & GARCH(1) & GARCH(1,1) \\
\hline C & 58.26325 & 17.29930 & 1.720871 \\
\hline e1 & 0.0000 & 0.8310 & 0.0205 \\
\hline e2 & & & 0.0001 \\
\hline $\boldsymbol{\alpha} \mathbf{1}$ & & 0.3685 & 0.0000 \\
\hline $\boldsymbol{\alpha} \mathbf{2}$ & & & \\
\hline AIC & 12.52390 & 12.52874 & -5.068634 \\
\hline SC & 12.54375 & 12.55850 & -5.019019 \\
\hline
\end{tabular}

Tabel4.9. Kesimpulan modelARCH/GARCH HargaIndeks Saham

\begin{tabular}{lccccc}
\hline $\begin{array}{l}\text { Indeks } \\
\text { Saham }\end{array}$ & Konstanta & $\begin{array}{c}\text { Koefesien } \\
\mathcal{E}^{\boldsymbol{t . 1}}\end{array}$ & $\begin{array}{c}\text { Koefesien } \\
\mathcal{E}^{\boldsymbol{t . 2}}\end{array}$ & $\begin{array}{c}\text { Koefesien } \\
\boldsymbol{h}^{\boldsymbol{t}-\mathbf{1}}\end{array}$ & $\begin{array}{c}\text { Koefesien } \\
\boldsymbol{h}^{\boldsymbol{t}-\mathbf{2}}\end{array}$ \\
\hline IHSG & $-2.92 \mathrm{E}-06$ & 0.0000 & 0.0000 & 0.0000 & 0.0000 \\
JII & 1.720871 & 0.0205 & 0.0001 & 0.0000 & \\
\hline
\end{tabular}

Tabel 4.7 menunjukkan bahwa e1 dan e2 adalah ARCH dan $\sigma 1$ dan $\sigma 2$ adalah GARCH. Pemilihan ARCH/GARCH yang terbaik dilakukan dengan melihat nilai AIC dan SC yang terendah di antara model ARCH/GARCH yang diolah. Untuk harga minyak mentah jenis WTI, model ARCH/GARCH yang terbaik dengan nilai AIC dan SC terendah adalah GARCH $(2,2)$. Parametenya pun signifikan terhadap taraf nyata $5 \%$.

Selanjutnya table 4.8, menunjukkan bahwa e1 dan e2 adalah ARCH dan $\sigma 1$ dan $\sigma 2$ adalah GARCH. Pada minyak mentah jenis Brent ini pun di pilih model GARCH $(1,1)$ dan model ini menjadi model yang terbaik karena AIC dan SC dari model tersebut merupakan yang terendah di antara yang lainnya. Selain itu, parameternya pun signifikan terhadap taraf nyata $5 \%$.

Tabel 4.9 menyimpulkan bahwa harga indeks saham IHSG dipengaruhi oleh nilai $\operatorname{ARCH}(\varepsilon t-12)$ atau volatilitas pada periode t-12 dan nilai GARCH(ht-12) atau varian periode $\mathrm{t}-12$. Kemudian hasil yang sama pula ditunjukkan oleh indeks harga saham JII di mana dipengaruhi oleh nilai $\operatorname{ARCH}(\varepsilon t-12)$ atau volatilitas pada periode $\mathrm{t}-1$ dan nilai GARCH(ht-1) atau varian periode $\mathrm{t}-1$.

\section{Peramalan (forecasting)}

Setelah menentukan model yang terbaik, langkah selanjutnya adalah peramalan, dalam hal ini menggunakan model GARCH $(2,2)$ untuk IHSG dan GARCH $(1,1)$ untuk JII. Model ini dipilih sesuai dengan kriteria pemilihan model terbaik. Berikut adalah hasil peramalan yang diperoleh dari program $e$-views. 
Jurnal Ekonomi dan Perbankan Syariah

Vol. 3. No.1, April 2015: 69-84, ISSN (cet): 2355-1755
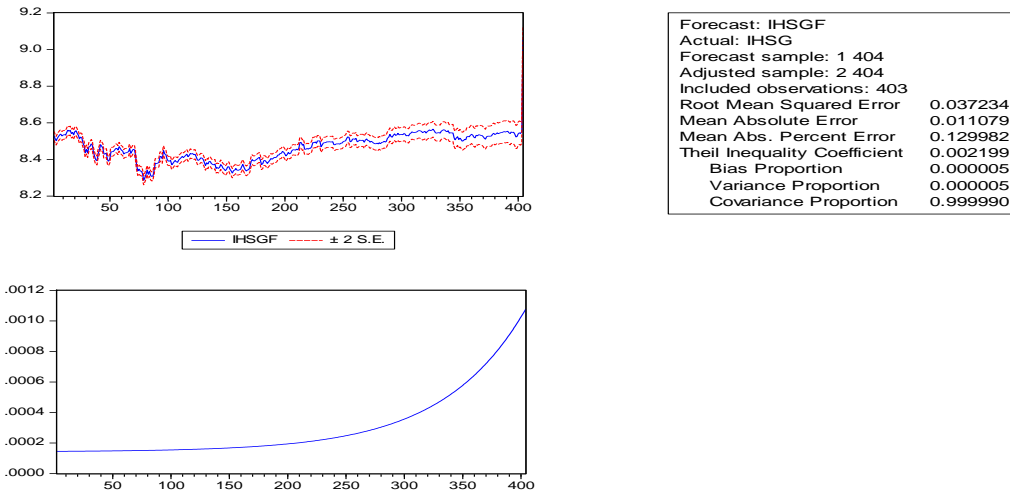

Gambar 4.8 Forcest of variance GARCH $(2,2)$ JII
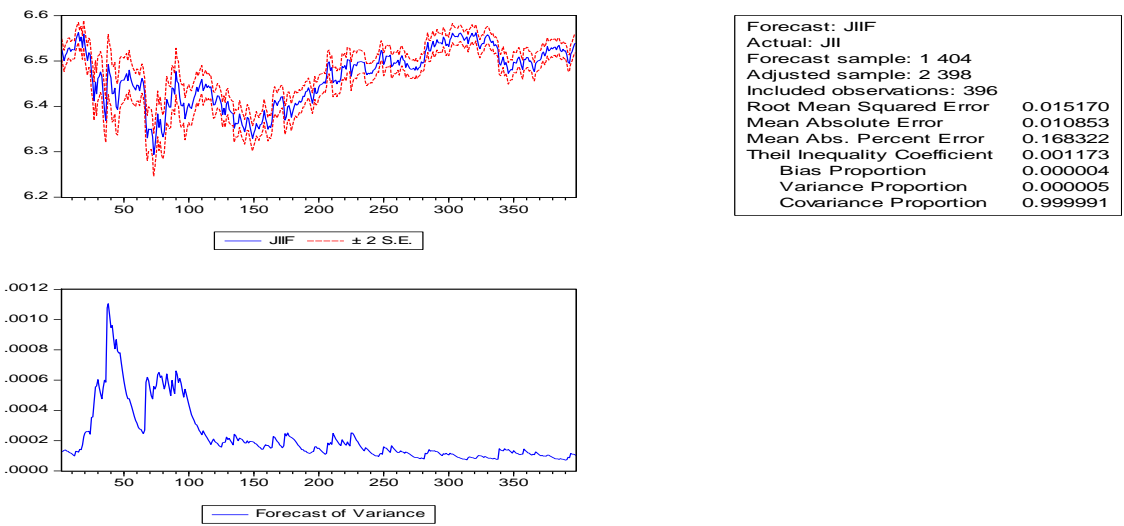

Grafik 4.7 dan 4.8 menunjukkan varian yang akan datang dari harga saham IHSG dan JII. Dengan menggunakan model ARCH/GARCH ini, bisa terlihat dari kedua grafik tersebut potensi resiko harga yang terus berubah dan berfluktuasi. Secara angka proporsi varian antara harga saham IHSG dan JII memiliki angka proporsi varian yaitu 0.000005 . Namun, jika dilihat dari proporsi biasnya ada perbedaan yang sangat tipis antara keduanya. Di mana proporsi bias untuk IHSG sebesar 0.000005 sedangkan proporsi bias untuk JII sebesar 0.000004 . Artinya proporsi bias harga saham IHSG lebih besar daripada proporsi bias harga saham JII.Dengan kata lain harga saham IHSG lebih beresiko dibandingkan dengan harga saham JII.

\section{SIMPULAN}

Hasil uji heteroskedastis terhadap dua indeks harga saham menunjukkan angka yang signifikan (lebih kecil dari 5\%). Hal ini berarti model ARCH/GARCH lebih tepat untuk digunakan dalam penelitian ini dibandingkan dengan ARIMA. GARCH $(2,2)$ adalah model yang terbaik untuk digunakan sebagai model analisis volatilitas harga indeks saham IHSG dan sedangkan GARCH $(1,1)$ adalah model yang terbaik untuk digunakan sebagai analisis volatilitas harga indeks saham JII. 
Kemudian dari hasil forecast of variance menunjukkan bahwa fluktuasi dan proporsi varian IHSG dan dan JII sama yaitu sebesar 0.000005, di mana sekitar tahun 20132014 merupakan tahun politik di Indonesia. Namun jika melihat kepada proporsi bias harga indeks saham IHSG lebih tinggi resikonya dibangdingkan dengan JII, yang mana proporsi bias IHSG sebesar 0.000005 dan proporsi bias JII sebesar 0.000004 . Artinya resiko volatilitas IHSG lebih tinggi dibandingkan resiko volatilitas yang ada di JII.

\section{DAFTAR PUSTAKA}

Aritonang, R. (202). Peramalan Bisnis. Jakarta: Ghalia Indonesia.

Aswandi, Anggreyani, D., \& Nurfalah, I. (2014). Analisis Komparatif Volatilitas Pasar modal dan Pasar Modal Syariah di Indonesia dan Pakistan dengan metode GARCH.

Eliyawati, W. Y., Hidayat, R. R., \& Azizah, D. F. (2014). Penerapan Model Garch (Generalized Autoregressive Conditional Heteroscedasticity) Untuk Menguji Pasar Modal Efisien Di Indonesia (Studi pada Harga Penutupan (Closing Price) Indeks Saham LQ 45 Periode 2009-2011) . Jurnal Administrasi Bisnis (JAB) Vol 7. no 2 .

Engle, R. F. (1987). Autoregressive Conditional Heteroscedasticity with Eestimates of the Variance of United Kingdom Inflation. Econometrika, Vol 50, no 44 .

Fahmi, I. (2013). Pengantar Pasar Modal. Bandung: Alfabeta.

Fauziah, N. (2013). Skripsi: Analisis Pengaruh Volume Perdagangan, Inflasi, Deviden, Pay Out Ratio Terhadap Volatilitas Harga Saham Perusahaan Yang Terdaftar Di LQ45.

Firmansyah. (2006). Analisis Volatilitas Harga Kopi Internasional Jakarta : Usahawan.

Gumanti, T. A. (2011). Manajemen Investasi Konsep,Teori dan Aplikasi. Jakarta: Mitra Wacana Media.

Husnan, S. (2009). Teori Portofolio dan Analisis Sekurietas. Edisi keempat. Yogyakarta: UPP STIM YKPN.

Islam, M. A. (2014). Aplying Generalized Autoregressive Conditional Heteroscedasticity Models Univariate Volatility. Journal of Applied Sciences 14 (7) .

Jati, K. (2014). Analysis of Sugar Prices Volatility Using ARMA and ARCH/GARCH. International Journal of Trade, Economics and Finance, Vol. 5, No. 2 .

Juanda, B., \& Junaidi. (2012). Ekonometrika Deret Waktu Teori dan Aplikasi. bogor: PT penerbit IPB Press.

Kartika, A. (2010). Volatilitas Harga Saham di Indonesia dan Malaysia.

lestari, e. (2008). perbandingan kinerja pasar modal syariah dan konvensional di Indonesia: pendekatan volatilitas. Dalam E. L. Mohammad Nadjib, investasi syariah implementasi konsep pada kenyataan empirik. yogyakarta: KREASI WACANA.

Masa Depan Pasar Modal Syariah di Indonesia2014jakartaPRENADAMEDIA GROUP

Maskur, A. (2009). Volatilitas Harga Saham antara Saham Konvensional dan Syariah.

Rivai, V., \& Buchari, A. (2013). ISLAMIC ECONOMIC : Ekonomi Syariah bukan Opsi tetapi Solusi. jakarta: BUMI AKSARA.

Rodoni, A., \& Hamid, A. (2008). Lembaga Keuangan Syariah. Jakarta: Zikrul Hakim.

Rojin, A., Kusdarwati, H., \& Sumarningsih, E. (t.thn.). peramalan volatilitas ihsg dengan menggunakan model stochastic volatility. 